\title{
Teaching Profit Seeking as the Source of Growth
}

\author{
David Kauper
}

\begin{abstract}
This paper offers an alternative to the typical presentation of economic growth theory in standard introductory textbooks. The standard textbook presents neoclassical production functions with diminishing marginal returns and predictions of convergence. For many students, the incentives to learn this are weak since the theory is abstract and its initial predictions inaccurate. A few changes to the presentation can create clarity and believability. One change is to present both creative destruction and rent seeking as possible paths of the profit motive. In this case, not only can students find greater consistency with their own observations, whereby profits can be well-earned or ill-gotten, but students can find consistency with the cross-country data and the simultaneous existence of converging and diverging countries. Students will be more motivated to understand neoclassical production functions with diminishing returns, since they are relevant for all countries of the world, not just an abstract few.
\end{abstract}

JEL classification: A22

\section{Introduction: Improving Pedagogic Delivery of Economic Growth}

Much of the emphasis of improving classroom effectiveness has been on style and technique-how to motivate students; how to identify and accommodate individual learning styles; how to move beyond the "chalk and talk" using discussions, simulations, technology, and peer and experiential learning (for example, see McKeachie et al., 2006 and Lowman, 1995). Less emphasis has been put on content.

Colander (2004) argues "that content, not form is what is central to economics teaching." He concedes that students need to be motivated, but that good content will convince students of the subject's importance even when that content is poorly delivered (ibid, p. 63). Economic knowledge has been constructed over centuries and is continually growing. Faculty should distil this information for students so that they can make practical use of it, even when it necessitates learning terminology and memorising models. He summarises: "To be a good teacher one must have something to teach..." (ibid, p. 73).

My goal in this paper is to improve the distillation of the content in Introductory Macroeconomics by reorganising typical textbook treatments so as to facilitate student learning. Despite other options, textbooks typically follow the historical progression of the neoclassical growth literature. The seminal works of Solow (1956) and Swan (1956) centre on the accumulation of physical capital and this emphasis has continued in the literature for decades, such as in the highly cited papers, Barro (1991) and Barro and Sal-i-Martin (1992), Mankiw et al. (1992), Young (1995), and DeLong (1997). Unsurprisingly, the accumulation of physical capital and exogenous technological change alone were not enough to explain the empirical data. As the literature sought further refinements, it added endogenous growth, human capital and institutions to the models (Romer, 1986 and 1990; Grossman and Helpman, 1991; Becker, 1964; and Knack, 2003, et al.). 
There are some pedagogic drawbacks to following the historical literature. One is an overemphasis on capital accumulation, despite our current understanding of the importance of technology, human capital and institutions. Another problem is that the first test of our growth model fails for our students. We fail to find absolute convergence, when we should be testing for conditional convergence.

I sense that students reject the economics we teach because it poorly describes the world they know. They know a world where the latest technology means more to their lives than does a large factory. They know of a wealthy United States, a rising China and an impoverished Haiti. We can explain that world with current economic theory, but not using a model from 1956; no matter how important that model is to our current economic understanding.

I propose that we teach production functions and conditional convergence, but in a sequence in which we transition from students' observations to researchers' models, instead of jumping to oversimplified abstract models and then refining them. From students' observations we can identify sources of growth, then categorise them using economic terminology and finally integrate them into production functions and economic models. In this way, we can minimise the number of students whose attention we lose because our interim story is so unfamiliar and incomplete.

My proposed presentation starts with firms' profit seeking as a choice between production and predation, or alternatively, creative destruction and rent seeking. Creative destruction generates growth and several sources are enumerated: investment in physical capital, human capital and technology; increased savings rates; and establishment of efficient institutions, in other words institutions that encourage creative destruction and discourage rent seeking. Some sources of growth exhibit increasing returns while others exhibit decreasing returns. Depending on the particular combination of sources of growth pursued, countries might quickly or slowly converge or diverge.

None of this is new economic theory. Thomas Carver argued for the benefits of production versus predation in 1917. Joseph Schumpeter popularised the term creative destruction in 1942 and Anne Krueger popularised the term rent seeking in 1974. Economists have long written about these sources of growth. Adam Smith wrote about the importance of physical capital, saving and investment in Book II: Of the Nature, Accumulation, and Employment of Stock, of what today would be called human capital and technology in Book I: Of the Causes of Improvement in the productive Powers of Labour, and of the Order according to which its Produce is naturally distributed among the different Ranks of the People, and of institutions in Book IV: Of the Systems of political Economy and Book V: Of the Revenue of the Sovereign or Commonwealth (1776).

For centuries we have known that investment returns depend on the size of the economy. In 1776, Adam Smith saw larger markets allowing increasing returns in the specialisation within pin manufactories (Warsh, 2006). In 1817, David Ricardo taught us the importance of diminishing marginal returns in determining rents. Hundreds if not thousands of writers since Smith and Ricardo, and since the Marginalist Revolution, have worked to model and quantify these variables and their interrelationships.

In that empirical and theoretical work, economists have already proposed a world of convergence, divergence and experiences in between. Abramovitz (1986), Young (1995) and many others have described and explained convergence. Paul Romer (1986 and 1990) and Aghion and Howitt (1997) explicated endogenous growth. Many, including Rosenstein-Rodan (1943), Lewis (1954) and Murphy et al. (1989), have offered explanations of poverty traps. Economists have argued that the patterns of growth are varied and depend on multiple variables. Mankiw, Romer, and Weil (1992) take Solow (1956) and his residual seriously and find strong empirical evidence for conditional convergence. Hausmann et al. (2006) approach diverse empirical patterns with a trouble-shooting guide of growth diagnostics. 
While much work remains, economists have a strong, workable understanding of the mechanisms of growth. However, I recommend against teaching it the way we understand it. We learn new material by building on current understanding (Bain, 2004). Undergraduates' initial understanding is very different from professional economists'. Economists start with models of production functions and build upon them with capital, technology and saving. Solow leads to Paul Romer, then Mankiw, and then Rodrik. Undergraduates are not entering the classroom with Solow. They come with models of rich and poor, good and bad, and money paid to businesses such as Walmart and McDonald's. In order to bring them to our economic understanding, replete with formal, mathematical models, we must start with theirs.

In the remainder of the paper, I characterise our students and their mental models, summarise the treatment of growth in the typical introductory textbook, and outline my proposed treatment, followed with conclusions.

\section{Teaching Content: Know Your Audience}

Students have been learning how the world works for approximately two decades before they enter the classroom to learn economics. The students are confident in their ability to navigate this world and they have also learned that often others are wrong, whether by accident, naïveté or intention. When students hear something inconsistent with their own views, some struggle to learn it and others simply learn it superficially without changing their own views of the world (Bain, 2004). They memorise simply to pass the course, but they do not believe it.

This creates a challenge for teachers who want the trusting students to have an easier time learning and the cynical students to benefit in the long run from our best, current economic theory. One approach starts with what students already know, challenges them with questions that their current mental models cannot satisfactorily answer, and then adds new content that builds upon their existing models such that it can better resolve inconsistencies (Bain, 2004, chpt 2). This is generally how knowledge is constructed anyway (ibid, p.26), however in a well-designed course the instructor, as the expert, guides the students through the process (Colander, 2004, p. 67). So, we should start with the initial mental models of our students, not our discipline, and build upon them to create our economic models.

Possibly the most common preconceived attitudes brought by students are their judgments regarding the social value of free-market capitalism. Some students arrive with supreme faith in the power of markets to generate efficiency or socially optimal outcomes. They are likely to expect course content to validate this and when it does not, they could dismiss the instructor as just another liberal professor.

Liberal students are also easily disappointed in an economics course. They might arrive viewing businesses as cold-hearted with socially inefficient and unjust outcomes since, in their view, the wealth of the business owners is created by the toil of the workers. In this zero-sum-game world, the rich have gained at the expense of the poor, whether at the individual or national level. The professor that extols the virtues of profit-maximising self-interest is easily dismissed as an unfeeling, shallow-minded economist.

Both extremes reflect some truth and acknowledging that can make a course more effective. Increasing productive efficiency and product development benefits society and can enrich individuals as well as corporations. However, wealth can come at the expense of others. Monopolists transfer welfare from consumers, as can any firm with asymmetric information. If profit seeking is introduced as neutral, then all interested students' views are validated. After the students see that their basic observations are correct, then more material can be added to make the transition to the typical economic model of wealth-generating profits complete with caveats. This should encourage the students to take our knowledge more seriously. We are supplementing their knowledge, not taking away from it. 
How else do students learn? Permanent learning occurs when new material is connected to existing (Lowman, 1995, p. 135). This principle is relevant not only for building upon the students' existing mental models, but also for the development of the new economic material in the course. Students have already seen thriving businesses in action; they have been to restaurants, retail stores, beauty salons, etc. These businesses have the manifestations of economic growth, they have physical capital and technology, and the workers have skills. At some level, the students realise that this increases worker output, so this is a good place to start. The students can visualise these sources of growth and then learn to think of them in economic ways, using economic terminology.

When the ideas are dissimilar, students will learn them more easily if they are connected by a common theme (ibid, p. 135). Various business activities can be lumped together as profit seeking, even if it does not generate economic growth. All of the various sources of growth can be lumped together as ways to increase the supply curve. The varied combinations of national output levels and growth rates can be seen as the interplay between sources of growth with diminishing returns and those with increasing returns. With just a few themes, we can recreate the myriad of business activities seen by students as well as the panoply of national experiences.

\section{The Typical Intro Textbook Sequence}

When addressing economic growth, the typical introductory textbook discusses the importance of growth, then presents the aggregate production function and uses it to demonstrate an abstract process of economic growth-i.e. shifts of curves and movement along curves. The typical textbook then concludes by discussing the weaknesses of the model; see Baumol and Blinder (2008), Case et al. (2009), Colander (2009), Hubbard and O'Brien (2009), Krugman and Wells (2009), Mankiw (2001), Parkin (2010), and Stiglitz and Walsh (2002).

Learning about growth is motivated by the importance of growth. Our standard of living is determined by the amount of output per person. This standard of living has risen over the decades due to growth of labour productivity. Even small differences in growth rates have an enormous impact on living standards, as can be seen in the rule of seventy.

The primary sources of productivity are physical capital, human capital and technology. Physical capital is the man-made factor of production, including buildings and equipment. Human capital includes the skills and knowledge embodied in the workforce. Technology refers to the methods for combining resources into goods and services-i.e. the blueprints for production. As an economy accumulates these resources, productivity and standard of living rise.

The positive relationship between capital and productivity can be plotted as the production function. Because of diminishing marginal returns, the upward-sloping production function gets flatter as physical capital per worker is increased. Growth is represented by higher levels on the vertical axis. This can occur through capital accumulation-i.e. a movement along the curve-or investment in education or research and development of new technologies-i.e. upward shift of the curve.

Countries grow at different rates because they vary in the rates of accumulation of physical capital, human capital and technology. They can also grow at different rates due to differences in saving rates, level of foreign investment and institutions. Essentially, each country must be looked at individually to see why they are or are not growing, but economic theory does offer some suggestions.

And the theory can be tested. Because of diminishing marginal returns to capital combined with the public-good characteristic of technology, poor countries should grow faster than rich ones-i.e. the convergence hypothesis. Unfortunately, the data only weakly support this conclusion. China and the East Asian Miracle corroborate the theory, but Latin America and Africa refute it. Near the end of the chapter, institutions and spill-overs appear as afterthoughts used in an ad hoc way to make simplistic 
models fit the data of conditional convergence. The students just completed a chapter without clear benefit due to its awkward explanation of the world.

How well does this treatment address student learning? We probably have not changed their understanding of the world, since the students can learn this theory in parallel to their own. They simply need to memorise a short list of sources of growth and then learn the relationships of the production function. However, they likely cannot apply what they have learned because not only has it not changed their own beliefs, but the economists developing it appear to struggle in applying it.

Whatever beliefs brought by the students about the morality behind profit seeking most likely have not changed. They can easily conclude that Latin America and Africa remain poor because of exploitation or conclude that Asia is becoming rich because of free markets. The emotionally leaning socialists still have faith in generosity and the emotionally leaning libertarians still have faith in greed. The apathetic still think an opinion is a waste of time. Completing the chapter has not modified the students' world outlook.

The students are required to learn an ad hoc list of a few sources of growth. It is not clear which are more important than others. On the one hand, physical capital seems to be the most important because there is a graph based on it. On the other hand, human capital and technology are described as very important. But then why are so many countries not converging? Many reasons are offered. It is not clear what is really significant.

The chapter portrays an uncertain theory instead of a nuanced view of a complex world. Instead of describing the quantitative interplay between just a few forces, it introduces variables, one by one, adding more as necessary until all of the world's regions are explained. This seems to suggest that different regions follow different theories instead of a unified theory. Endogenous growth seems to be a competing view from diminishing returns instead of a concurrent force. Capital accumulation seems to lead to institutions instead of the other way. The students are struggling with ideas we did not mean to imply.

Of course, in the economics literature, just as in science, there is little certainty as new evidence either challenges or supports prior evidence. It is a slowly morphing body of knowledge. Eventually students should learn to confront this uncertainty and be comfortable enough to challenge it with new knowledge. However at the principles level, students should learn the basic body of knowledge that is almost certainly true, and they should learn it as if it is almost certainly true. They should come away from the course feeling that they have learned something valuable and that economics is a discipline with valuable things to say. Most of the students in an Introductory Macroeconomics course will likely not take another one, other than business majors required to take microeconomics. An effective presentation of the content will leave knowledge with the students, preferably for the rest of their lives.

\section{A Unified Approach to Growth Theory}

\section{Rent Seeking and Creative Destruction}

A good place to start in teaching the course content is with general themes that have broad applicability and are generally accepted by students. Two such economic themes are the rationality postulate and the model of supply and demand. Although rational self-interest has recently been coming under more scrutiny in the literature and media, nevertheless students seem to generally accept it and view the exceptions as either, an intermediate tactic, moral high ground, or personal obstacle. In other words, generosity can have karmic benefits, compassion is socially idealistic and socially contrived, and impulsiveness is a poor strategy of long-run practical hedonism. All the while, self-interest is the basic behaviour. 
The model of supply and demand is so ingrained in students that it often becomes their default answer under uncertainty. They seem to have no trouble understanding and using it.

These two economic themes can be the starting point for teaching economic growth. The producer surplus indicates the profit to firms. Firms want to maximise their producer surplus. The students now have a foundation by applying the rationality postulate to the model of supply and demand.

The economics immediately gets interesting by realising that profit seeking leads to various moral outcomes for society. Firms can create rent by increasing either the supply or demand curve, or they can appropriate rent by capturing either the consumer surplus or resource rents. Two popular terms for these activities are creative destruction and rent seeking.

Creative destruction generates welfare by increasing the size of consumer and producer surpluses combined (see Figure 1). Although motivated by producers' profits, it can even have a disproportionate benefit for consumers following an increase in supply. This is the capitalism that generates the BMW M3, Apple iPhone, Avatar in 3-D, Nintendo Wii and countless other products so loved by students.

Figure 1

A:

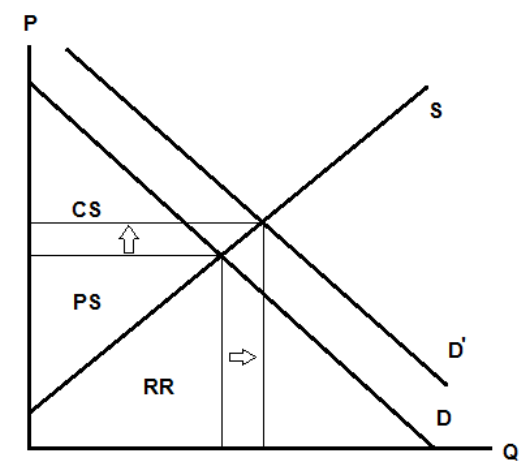

B:

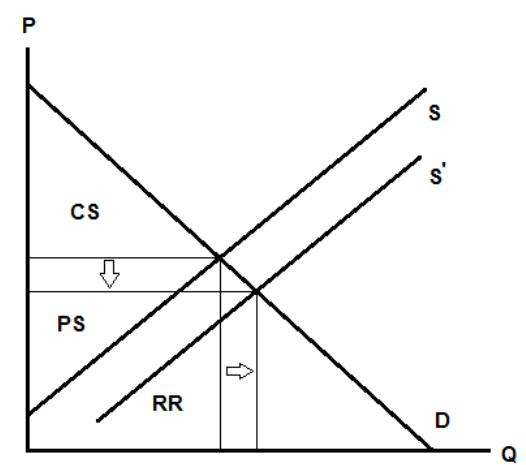

Creative Destruction increases total welfare. Panel A: following an increase in demand (D), producer surplus (PS) and resource rents (RR) grow, but the net change in consumer surplus (CS) is ambiguous. Panel B: following an increase in supply (S), consumer surplus grows, but the net changes in producer surplus and resource rents are ambiguous.

On the other hand, rent seeking decreases total welfare in society by generating a deadweight loss and opportunity costs from investing in unproductive activities (see Figure 2). Economics' most commonly cited example is the monopolist and a monopolist must reduce output in order to increase price and spend to maintain market power, possibly through lobbying or bribery, depending on the country and economy. 


\section{Figure 2}
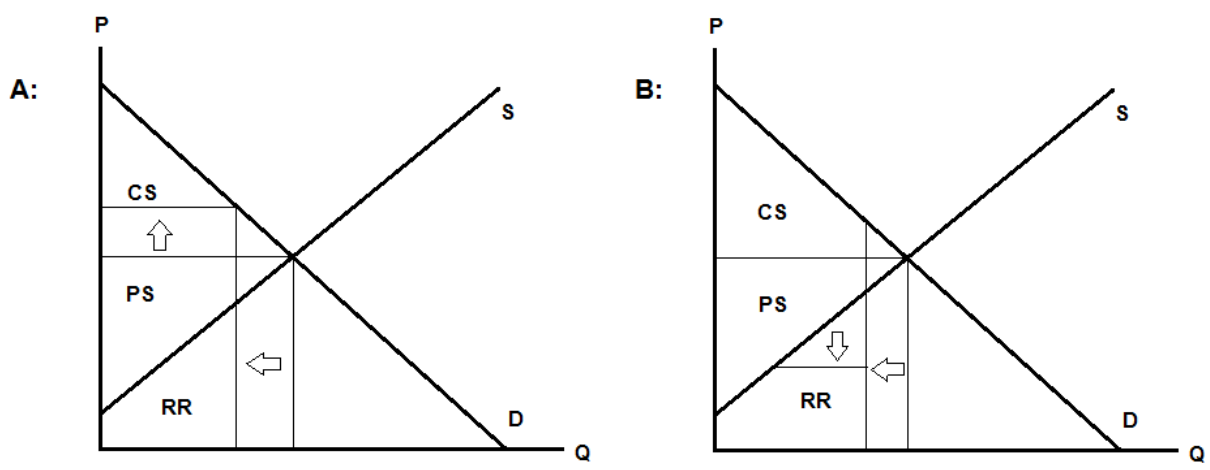

Rent seeking decreases total welfare. Panel A: a monopolist using market power to capture consumer surplus (CS) by charging a higher price for output. Panel B: a monopsonist using market power to capture resource rents (RR) by paying a lower price for inputs. Notice that this is in contrast to lowering costs by needing fewer resources (i.e. increasing productivity through creative destruction).

Rent seeking is the form of capitalism that generates NINJA loans (principal-agent problems as brokers and credit-rating agencies set values according to their interests instead of the interests of their principals), hand-crank windows and cacophonous seat-belt buzzers on entry-level cars (price/quality discrimination through product differentiation when buyers show brand loyalty (Kwoka, 1992)), and NCAA rules for amateur athletics (monopsonies as buyers form cartels, set near zero prices and impose penalties for violators), among other business practices. At a national scale, rent seeking can lead to thievery, slavery and war.

A profit maximising firm will pursue both strategies depending on the incentives imposed by society and balance the two strategies depending on the relative rates of return. Walmart provides familiar and emotionally-charged examples. Walmart attracts customers on Black Friday by offering a few products at extremely low prices. Most of the hopeful customers will buy from Walmart without obtaining one of the advertised discounts, thereby allowing Walmart to capture more revenue than consumers expected to pay. The use of loss leaders has occasionally even had fatal results (McFadden and Macropoulos, 2008).

In addition to seeking consumer surplus, Walmart seeks resource rents. Walmart is notorious for its efforts to limit unionisation and for its negotiation tactics with suppliers. Typically Walmart is able to prevent unionisation, but a rare success by union organisers resulted in Walmart closing the store (Fishman, 2006, p. 48). Walmart negotiates fiercely with its product suppliers as well. In Spartan cubicles at its Bentonville headquarters, suppliers face demands of lower costs if they want a chance to sell to the largest retailer in the world. Few reject Walmart's terms despite shrinking margins (ibid, chpt 5).

Besides rent seeking, Walmart pursues creative destruction. Recently, Walmart initiated Project Impact with the intent to improve the customers' shopping experience with "cleaner, less cluttered stores" and "friendlier customer service" (Gregory, 2009). Walmart.com lists "more than half a million items" for sale, providing customers with a large variety from one source (Walmart, 2009). These features increase the demand for Walmart's retail services.

Walmart is most famous for its innovations in logistical efficiency which lowered production costs and increased supply. Walmart "became a model of a vertically integrated supply chain, complete with automatic replenishment of our stores' inventories as well as co-managed inventories with many of our suppliers" (Soderquist, 2005, p. 153). Walmart incorporated management information systems and 
brought just-in-time to retailing. This contribution is so significant that some research credits Walmart for much of the relative increase in U.S. productivity growth in the 1990s (Johnson, 2002 attrib. Krugman and Wells, 2009 and attrib. Soderquist, 2005). Although discussing Walmart can be quite emotional, it is the world's largest corporation ("Global 500", 2010) and should be understandable to students. Nonetheless, I am confident that a review of any large corporation would also yield multiple examples of each type of profit seeking, whether creative destruction or rent seeking.

Now that students have had the opportunity for their own observations to be confirmed and broadened, we can assess the social costs and benefits of profit seeking. Creative destruction generates growth. Monopolistically-competitive firms continually introduce new products and production methods in order to stay in business. Society benefits from the innovation while the old technologies and the firms hanging on to them are wiped out (Schumpeter, 1942). Graphically, either increasing the supply or demand curve increases total welfare in the economy.

Rent seeking slows growth. Monopolies and monopsonies force market prices away from welfaremaximising values resulting in deadweight losses (Harberger, 1954). Other deadweight losses result when potential buyers do not participate in markets due to asymmetric information (Akerlof, 1970). Potentially larger are the opportunity costs that arise from investments made in pursuit of rent seeking instead of creative destruction (Krueger, 1974). Beyond merely wasting resources that could have gone to output, rent seeking wastes resources that could have generated growth. Every dollar spent on the appropriation or protection of wealth and resources could have been invested in capital accumulation, education, health or research and development, but is not when firms decide that rent seeking is more profitable. One manifestation at the national scale is the resource curse in which resource-rich countries exhibit below-average growth rates (Sachs and Warner, 2001).

How do we balance rent seeking and creative destruction? Institutions "are the underlying determinant of the long-run performance of economies" (North, 1990, p. 107). A society's rules and values will decide the incentives for stealing, colluding, learning and researching. Good institutions will discourage rent seeking and encourage creative destruction, in all of their manifestations.

More specifically, "institutions are decisive for the resource curse" and influence whether natural resources become an asset or an economic distraction (Mehlum et al., 2006, p. 1). Corruption signals rent seeking and lower levels of it are associated with dynamic efficiency and the realisation of potential growth (Kauper, 2010). Institutions alter Walmart's incentives between rent-seeking and creative destruction. Consumer protection laws regarding truth in advertising and the provision of rain checks influence the benefits of promoting loss leaders. Labour laws regarding employer rights to union opposition and rules of organising alter the calculus of effort for both sides. When institutions can channel self-interest into creative destruction, free-market capitalism is socially beneficial.

\section{From Creative Destruction to Increasing Supply}

At this point in the lecture(s), the students should have the sense that they and their dissenters both have valid observations regarding individual self-interest and social welfare. Society's challenge lies in knowing which incentives will best exploit self-interest for society's gain. The next task in the classroom is for the students to understand the mechanisms for growth through creative destruction, and again the place to begin is with what the students already know.

Long before taking a macroeconomics course, students have already seen various manifestations of firms increasing supply. Many businesses provide a wide range of examples of economic investment. Either the students or the instructor can begin by providing specific examples and then the instructor can classify those by economic terminology. See Table 1 for possible examples from a hypothetical McDonald's restaurant. 
Table 1: Ways to Increase Supply

\begin{tabular}{|c|c|c|}
\hline How could a McDonald's increase the quantity supplied? & $\begin{array}{l}\text { Economy-wide economic } \\
\text { term-i.e. source of growth }\end{array}$ & Returns* \\
\hline Use more ingredients: e.g. more potatoes & Increase in natural resources & \\
\hline Hire more workers: e.g. more cashiers & Increase in labour & \\
\hline Use more equipment: e.g. more cash registers & Increase in physical capital & - \\
\hline $\begin{array}{l}\text { Train workers: e.g. send managers to Hamburger } \\
\text { University }\end{array}$ & $\begin{array}{l}\text { Increase human capital- } \\
\text { education }\end{array}$ & - \\
\hline Reduce sick days: e.g. offer bonuses to non-smokers & Increase human capital-health & - \\
\hline $\begin{array}{l}\text { Use better ingredients: e.g. train suppliers in developing } \\
\text { countries to produce more uniform potatoes }\end{array}$ & Better soil, climate etc. & \\
\hline $\begin{array}{l}\text { Use more effective capital: e.g. use cash registers with } \\
\text { pictograms for keys }\end{array}$ & $\begin{array}{l}\text { Better technology embodied in } \\
\text { capital }\end{array}$ & - \\
\hline \multirow{2}{*}{$\begin{array}{l}\text { Use better procedures: e.g. have cashiers fill sodas while } \\
\text { waiting for order fillers to bring hamburgers and fries }\end{array}$} & Better technology-imitation & - \\
\hline & Better technology-innovation & + \\
\hline $\begin{array}{l}\text { Use better advertising: e.g. promote the reintroduction } \\
\text { of the } \mathrm{McRib}^{\circledR} \text { sandwich }\end{array}$ & $\begin{array}{l}\text { Reduce transaction costs- } \\
\text { search }\end{array}$ & \\
\hline $\begin{array}{l}\text { Provide uniform products: e.g. same hamburger by look } \\
\text { and taste throughout the United States }\end{array}$ & $\begin{array}{l}\text { Reduce transaction costs- } \\
\text { contract negotiation }\end{array}$ & \\
\hline $\begin{array}{l}\text { Provide quality guarantee: e.g. replace the hamburger of } \\
\text { any dissatisfied customer, no questions asked }\end{array}$ & $\begin{array}{l}\text { Reduce transaction costs- } \\
\text { contract enforcement }\end{array}$ & \\
\hline Find better location: e.g. closer to more traffic & $\begin{array}{l}\text { Reduce transaction costs-- } \\
\text { transportation }\end{array}$ & \\
\hline $\begin{array}{l}\text { Build better road to store: e.g. driveways with better } \\
\text { ingress and egress to a busy street }\end{array}$ & $\begin{array}{l}\text { Build infrastructure (reduce } \\
\text { transportation costs) }\end{array}$ & - \\
\hline
\end{tabular}

* "_" indicates a source of decreasing returns to development and " + " indicates a source of increasing returns to development.

Each of these sources of growth requires investment. Therefore, an indirect source of growth is to lower the cost of investment. Since the interest rate is the price of loanable funds and either an actual cost or opportunity cost of economic investment, then a lower interest rate can increase economic investment and growth. This lower interest rate can be attained through an increase in total savings or through more efficient financial markets. 
As previously described, since creative destruction is an opportunity cost of rent seeking, institutions that reduce rent seeking will increase creative destruction and economic growth. With this we can make a summary list including the most typical sources of growth from Table 1:

- Accumulation of physical capital

- Investment in human capital

- Building infrastructure

- Imitating and adapting existing technologies

- Innovation

- Higher saving rates, whether domestic or from (financial) capital inflow

- $\quad$ Better institutions

\section{Building and Testing the Theory: Divergence and Convergence}

How can this information be used to explain observed economic growth rates, predict trajectories of growth, and improve country performance? A good place to start is with the idea that the returnsincreasing or decreasing - to each source of growth will likely change depending on the level of development of the economy. In other words, as an economy grows its opportunities for growth will likely change. If there are increasing returns to development, then as a country develops, rates of return on additional investment should increase with the result that economic growth should accelerate and rich countries diverge from poor ones left in a poverty trap. On the other hand, if there are decreasing returns to development, then investment and growth should yield lower subsequent returns and poor countries should initially experience rapid growth which slows down as they converge to rich countries.

When should there be decreasing returns? If they can choose among specific alternatives within a source of growth, then rational agents will first choose options with the highest rates of return, followed by options with lower rates of return. For example, if a McDonald's manager can choose between the purchase of another cash register, oven, fryer, refrigerator, table or computer, then the rational manager will spend available funds on items that will increase profits by the largest amount. Likewise, if a franchisee is deciding where to open a new store, she will first choose the most profitable locations. Applying the principle of the lowest-hanging fruit implies that investment in physical capital yields diminishing marginal returns. This concept can be extrapolated to the national level, as the instructor would have likely shown in the chapter on aggregate supply and aggregate demand.

The principle of the lowest-hanging fruit should also apply to investment in human capital, infrastructure and the imitation of technologies. Elementary schools choose to teach reading and writing before macroeconomics. Efficient governments build bridges connecting large populations before they build a bridge to nowhere. Firms can choose among state-of-the-art and defunct technologies when copying others. The more outdated the firm's current technology, the larger the potential jump in productivity and hence the larger potential growth.

Of course, keeping one factor of production constant, for our purposes labour, more investment in another factor of production should yield diminishing returns as the balance of inputs shifts away from labour leading to crowding etc. 
In some instances, returns can increase with economic development. When a firm is developing a new technology, then it cannot apply the principle of the lowest-hanging fruit. Since the firm does not know which method will yield the best results, it cannot select it before selecting technologies with lower returns, suggesting that innovation should not be characterised by decreasing returns. Due to spillovers, technological and scientific progress should feed off of each other, generating an increasing rate of progress (Romer, 1986). This describes the history of the developed nations (Warsh, 2006).

Other societal features should exhibit increasing returns to development. If individuals are characterised by diminishing marginal utility, then it should be easier for them to save as their wealth increases. The greater savings combined with increasing efficiency in financial markets allow more economic investment in growth. Development should facilitate further development. Similarly, if economic justice is a normal good that also improves economic efficiency, development should build momentum. The Progressive Era brought rights and economic participation to women and minorities, and arrived with the growth of the middle-class. The Progressive Era also led to less corruption, which suggests less rent seeking and more creative destruction. This suggests that institutions exhibit increasing returns to development; the more developed the country, the easier it is for the country to pursue growth through better institutions, analogous to Rostow's precondition-to-takeoff stage of growth (Rostow, 1960).

In a static view, we can show sources of growth with decreasing returns with the standard, upwardsloping and concave production function. We could create a production function with an independent variable with increasing returns and get an upward-sloping, convex curve. By convention, the independent variable is physical capital, the curve is concave and investment in any other source of growth shifts the frontier upward.

What would a dynamic view to illustrate predicted patterns of growth look like? In this case, the growth rate is on the vertical axis and our independent variable is initial GDP per capita. If the sources of growth with decreasing returns dominate, then the frontier would be downward-sloping, indicating convergence. If the sources of growth with increasing returns dominate, then the frontier would be upward-sloping. At this point, simple theory alone cannot predict the slope of the frontier, so empirical evidence can help.

The data show that some countries are converging, while others are diverging, thereby suggesting that countries are investing in the various sources of growth in many different combinations with varying degrees of success (see Figure 3 ). The most efficient countries are in fact converging and are likely investing in sources of growth with decreasing returns, such as physical capital, human capital and imitation of technologies. Research on the East Asian Miracle confirms this (Young, 1995). 
Figure 3: Three Types of Countries

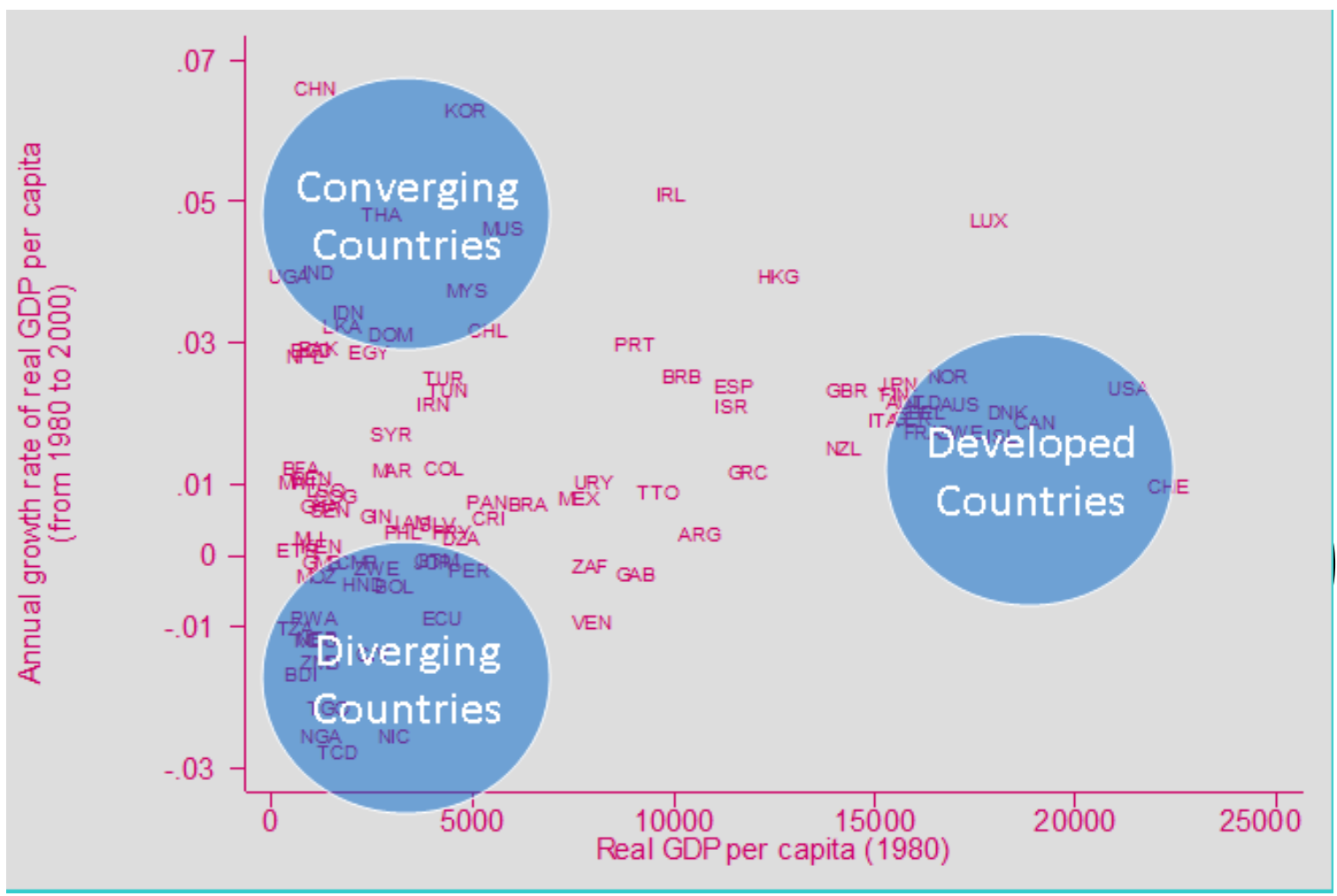

Average growth rates are from the PWT 6.1 (Heston et al., 2002). GDP is expressed in 1996 PPP dollars. Data points are represented by the International Organization for Standard's (ISO) three-letter country codes.

Diverging countries, on the other hand, do not seem to be taking advantage of opportunities for growth. This suggests that they are stuck in a poverty trap of low saving rates and institutions that favour rent seeking-in other words, the sources of growth with increasing returns. This is consistent with the many economists that argue the importance of institutions for development (Olson, 1996; Knack, 2003; Rodrik et al., 2004; and Kauper, 2010).

Although each country is unique, we can summarise the global situation for Intro students. Diverging countries, also known as developing or less-developed nations, need to improve their institutions so that the private incentives for profit seeking will generate creative destruction and not rent seeking. And they should increase their saving rates (or liberalise their capital inflows or devalue their currency). Converging countries, also known as emerging markets, are on the path to economic development by investing in physical capital, human capital and borrowing technologies from other countries. Developed countries are investing in capital and better institutions, but their key source of growth is the research and development of new technologies. Over time, the frontier should slowly shift out due to increasing returns to innovation; (see Figure 3). 


\section{Conclusion}

My proposed presentation begins with profit-seeking options of rent seeking or creative destruction. Creative destruction leads to growth and a variety of sources are considered. Depending on the sources pursued and the nature of the returns, poor countries might show convergence, divergence, or something in between. The ideas are not new, but the presentation is unusual.

Another option is to begin with textbooks specialising in economic growth, and then simplify them for introductory students. Barro and Sala-i-Martin have an extremely thorough textbook, Economic Growth (1995), but this advanced book is part of the preparation of professionals that will be reading from and contributing to journals that advance formal models to be used in empirical studies. Their objectives are different and consequently the authors skim intuition to leave space for derivations and data.

Many authors of upper-division textbooks on growth (see Jones, 2002 and Weil, 2005) do a wonderful job of building the intuition with lucid prose and vivid examples. However, they require an entire textbook with about a dozen chapters to do so. In order to leave time for business cycles and inflation in an Introductory Macroeconomics course, their textbooks would have to be condensed into a chapter or two. Because they go through the typical sequence of importance of growth, role of capital, Solow model, and so forth, this would leave us with the same limitations of a typical introductory textbook and our students with the same incredulity.

Some introductory textbook authors have seen a need to change the typical approach, one example being Cowen and Tabarrok with their textbook Modern Principles: Macroeconomics (2010). Before their treatment of the aggregate production function, they have an entire chapter on the basic intuition of economic growth, complete with the overview that institutions determine the incentives for investment in factors of production which generate GDP per capita (ibid, p. 98). That institutions matter is a key part of my proposed treatment. Nevertheless, my proposal goes even further by providing the context of rent seeking versus creative destruction leading to diverging, converging and developed countries.

Not all economists will accept my emphasis on institutions, my partition of country performance, or some other specific feature, and rightly so since many of our past quests have proved elusive (Easterly, 2001) and consequences unintended (Lal, 1998). When Lucas (1988) thinks about the causes of poverty and hardly anything else, he wonders whether it is the Indian government or its "nature" that is to blame, and economists are still debating that question. However, I have tried to be broad in encompassing many sources of growth and many possible outcomes, while limited in measuring and ranking them, thereby avoiding as much debate as possible.

I have tried to present a summary of the basic features of economic growth. Since this is likely the only time our students will hear our economic descriptions, we should prepare them with our best collective effort for years later when they need to vote amidst political rancour and have managerial plans despite planning to change them. Our students already face plenty of uncertainty and we can reduce it and add value with a presentation of the economic forces that we largely agree upon.

Unfortunately despite my empathy with them, many students resist my approach. Even though it is intended to confirm and build upon students' views, by expanding those views, it still challenges them and makes many students uncomfortable. Many are bothered by the notion that free markets are not a panacea. Others take umbrage in the suggestion that poor countries need to reform themselves and improve their own institutions. Some ridicule the thought that Walmart with its "always low prices" contributes to economic growth and well-being.

And many students still avoid the effort needed to understand the economic world. They know that they want a good grade, but are not so certain that the offered economic knowledge will actually be useful later in their lives. Given that calculus, they become cost-minimisers facing the fixed output of 
passing the exam. Consequently, they want study guides and lectures that stick to the textbook as closely as possible. Time spent on real-world applications seems wasted to them and deviations from the textbook merely confusing.

Nevertheless, I think that deviating from the textbook is worthwhile and that my proposed content accurately coalesces the cumulative work on economic growth to help students leave the course with lessons for a lifetime.

\section{References}

Abramovitz, M. "Catching Up, Forging Ahead, and Falling Behind." The Journal of Economic History, June 1986, Vol. 46(2), pp. 385-406.

Aghion, P. and Howitt, P. (1997). Endogenous Growth Theory, Cambridge, MA: The MIT Press.

Akerlof, G. A. (1970). “The Market for 'Lemons': Quality, Uncertainty, and the Market Mechanism,” Quarterly Journal of Economics, Vol. 84(3), pp. 488-500.

Bain, K. (2004). What the Best College Teachers Do, Cambridge, MA: Harvard University Press.

Barro, R. J. (1991). "Economic Growth in a Cross Section of Countries," Quarterly Journal of Economics, Vol. 98(5), Part II, S103-S125.

Barro, R. J. and Sala-i-Martin, X. (1992). "Convergence," Journal of Political Economy, Vol. 100(2), pp. 223251.

Barro, R. J. and Sala-i-Martin, X. (1995). Economic Growth, Cambridge, MA: The MIT Press, 1999.

Baumol, W. J. and Blinder, A. S. (2008). Macroeconomics: Principles and Policy, Cincinnati, OH: SouthWestern College Publishing.

Becker, G. S. (1964). Human Capital: A Theoretical and Empirical Analysis, with Special Reference to Education, New York, NY: National Bureau of Economic Research distributed by Columbia University Press.

Carver, T. N. (1917). "Production versus Predation," The Foundation of National Prosperity: Studies in the Conservation of Permanent Natural Resources, edited by R. T. Ely, R. H. Hess, C. K. Leith, and T. Nixon Carver, New York, NY: The Macmillan Company.

Case, K. E., Fair, R. C. and Oster, S. M. (2009). Principles of Macroeconomics, $9^{\text {th }}$ ed., Upper Saddle River, NJ: Prentice Hall.

Colander, D. (2004). "The Art of Teaching Economics," International Review of Economics Education, Vol. 3(1), pp. 63-76.

Colander, D. (2009). Macroeconomics, $8^{\text {th }}$ ed., New York, NY: McGraw-Hill.

Cowen, T. and Tabarrok, A. (2010). Modern Principles: Macroeconomics, New York, NY: Worth Publishers. 
DeLong, B. J. (1997). “Cross-Country Variations in National Economic Growth Rates: The Role of 'Technology'," Technology and Growth, edited by Jeffrey Fuhrer and Jane Sneddon Little, Boston, MA: Federal Reserve Bank of Boston.

Easterly, W. (2001). The Elusive Quest for Growth: Economists' Adventures and Misadventures in the Tropics, Cambridge MA: The MIT Press, 2002.

Fishman, C. (2006). The Wal-Mart Effect: How the World's Most Powerful Company Really Works-and How It's Transforming the American Economy, New York, NY: The Penguin Press.

“Global 500" (2010, July 26). Fortune, Retrieved January 13, 2011 from the World Wide Web: http://money.cnn.com/magazines/fortune/global500/2010/full list/index.html.

Gregory, S. (2009, September 9). "Walmart's Latest Move to Crush the Competition," Time, Retrieved June 19, 2010 from the World Wide Web: http://www.time.com/time/business/article/0,8599,1920698,00.html.

Grossman, G. M. and Helpman, E. (1991). Innovation and Growth in the Global Economy, Cambridge, MA: The MIT Press.

Harberger, Arnold C. (1954). "Monopoly and Resource Allocation in Factor Markets versus Product Markets," The American Economic Review, vol. 44, no. 2, pp. 77-87.

Hausmann, R., Rodrik, D. and Velasco, A. (2006). "Getting the Diagnosis Right: A New Approach to Economic Reform," Finance and Development, Vol. 43(1).

Heston, A., Summers, R. and Aten, B. (2002). Penn World Tables Version 6.1 (and Version 5.6), Center for International Comparisons at the University of Pennsylvania.

Hubbard, R. G. and O'Brien, A. P. (2009). Macroeconomics, $2^{\text {nd }}$ ed., Upper Saddle River, NJ: Prentice Hall. Johnson, B. C. (2002). “Retail: The Wal-Mart Effect," McKinsey Quarterly, February.

Jones, C. I. (2002). Introduction to Economic Growth, $2^{\text {nd }}$ ed., New York, NY: W.W. Norton \& Company.

Kauper, D. (2010). "Corruption and Efficiency," working paper.

Knack, S. (ed.) (2003). Democracy, Governance, and Growth, Ann Arbor, MI: The University of Michigan Press.

Krueger, A. O. (1974). "The Political Economy of the Rent-Seeking Society," The American Economic Review, Vol. 64(3), pp. 291-303.

Krugman, P. R. and Wells, R. (2009). Economics, $2^{\text {nd }}$ ed., New York, NY: Worth Publishers.

Kwoka, J. E., Jr. (1992). "Market Segmentation by Price-Quality Schedules: Some Evidence from Automobiles," Journal of Business, Vol. 65(4), pp. 615-628.

Lewis, W. A. (1954). "Economic Development with Unlimited Supplies of Labor," Manchester School of Economics and Social Studies, Vol. 22, pp. 139-191. 
Lal, D. (1998). Unintended Consequences: The Impact of Factor Endowments, Culture, and Politics on LongRun Economic Performance, Cambridge, MA: The MIT Press, 2001.

Lowman, J. (1995). Mastering the Techniques of Teaching, San Francisco, CA: Jossey-Bass.

Lucas, R. E., Jr. (1988). “On the Mechanics of Economic Development,” Journal of Monetary Economics, Vol. 22(1), pp. 3-42.

Mankiw, N. G., Romer, D., and Weil, D. N. (1992). "A Contribution to the Empirics of Economic Growth," Quarterly Journal of Economics, Vol. 107(2), pp. 407-437.

Mankiw, N. G. (2001). Principles of Macroeconomics, $2^{\text {nd }}$ ed., Orlando, FL: Harcourt College Publishers.

McFadden, R. D. and Macropoulos, A. (2008, November 28). "Wal-Mart Employee Trampled to Death," The New York Times, Retrieved June 19, 2010 from the World Wide Web:

http://www.nytimes.com/2008/11/29/business/29walmart.html.

McKeachie, W. J. et al. (2006). Teaching Tips : Strategies, Research, and Theory for College and University Teachers, Boston, MA: Houghton Mifflin Company.

Mehlum, H., Moene, K. and Torvik, R. (2006). "Institutions and the Resource Curse," The Economic Journal, Vol. 116(508), pp. 1-20.

Murphy, K. M., Shleifer, A. and Vishny, R. W. (1989). “Industrialization and the Big Push," Quarterly Journal of Economics, Vol. 106(2), pp. 503-530

North, D. (1990). Institutions, Institutional Change and Economic Performance, New York, NY: Cambridge University Press.

Olson, M. (1996). "Big Bills Left on the Sidewalk: Why Some Nations Are Rich, and Others Poor," Journal of Economic Perspectives, Vol. 10(2), pp. 3-24.

Parkin, M. (2010). Macroeconomics, $9^{\text {th }}$ ed., Boston, MA: Pearson Education.

Ricardo, D. (1817). On the Principles of Political Economy and Taxation, London: John Murray, AlbemarleStreet, 1821.

Rodrik, D., Subramanian, A. and Trebbi, F. (2004). "Institutions Rule: The Primacy of Institutions Over Geography and Integration in Economic Development," Journal of Economic Growth, Vol. 9(2), pp. 131-165.

Romer, P. M. (1986). “Increasing Returns and Long-Run Growth,” Journal of Political Economy, Vol. 94(5), pp. 1002-1037.

Romer, P. M. (1990). “Endogenous Technological Change,” Journal of Political Economy, Vol. 98(5), Part II, S71-S102.

Rosenstein-Rodan, P. (1943). "Problems of Industrialization of Eastern and Southeastern Europe," Economic Journal, Vol. 53(202/211), pp. 202-211. 
Rostow, W. W. (1960). The Stages of Economic Growth: A Non-Communist Manifesto, Cambridge, MA: Cambridge University Press.

Sachs, J. D. and Warner, A. (2001). "The Curse of Natural Resources," European Economic Review, Vol. 45, pp. 827-38.

Schumpeter, J. A. (1942). Capitalism, Socialism and Democracy, New York, NY: Harper and Row.

Smith, A. (1776). An Inquiry into the Nature and Causes of the Wealth of Nations, London: Methuen and Co, Ltd., (1904 edition).

Soderquist, D. (2005). The Wal-Mart Way: The Inside Story of the Success of the World's Largest Company, Nashville, TN: Nelson Business.

Solow, R. M. (1956). "A Contribution to the Theory of Economic Growth," Quarterly Journal of Economics, Vol. 70(1), pp. 65-94.

Stiglitz, J. E. and Walsh, C. E. (2002). Principles of Macroeconomics, $3^{\text {rd }}$ ed., New York, NY: W. W. Norton \& Company.

Swan, T. W. (1956). “Economic Growth and Capital Accumulation,” Economic Record, Vol. 32(2), pp. 334-361.

Walmart Stores, Inc. (2009, February). Walmart.com Fact Sheet, Retrieved June 19, 2010 from the World Wide Web, http://walmartstores.com/pressroom/factsheets/.

Warsh, D. (2006). Knowledge and the Wealth of Nations: A Story of Economic Discovery, New York, NY: W. W. Norton \& Company.

Weil, D. N. (2005). Economic Growth, Boston, MA: Pearson/Addison-Wesley.

Young, A. (1995). "The Tyranny of Numbers: Confronting the Statistical Realities of the East Asian Growth Experience," Quarterly Journal of Economics, Vol. 110(3), pp. 641-680.

\section{Author's note}

For their many helpful comments, I would like to thank Satyajit Ghosh and participants in the $85^{\text {th }}$ Annual Conference of the Western Economic Association International on July 3, 2010, Sean Flynn and participants in the 2010 Southern California Economics Teaching Conference on October 8, 2010, and two anonymous referees.

\section{Contact details}

David Kauper

Department of Economics, University of the Pacific, Stockton, CA 95211, United States of America Email: dkauper@pacific.edu 